\title{
Source attribution of the changes in atmospheric methane for 2006-2008
}

\author{
P. Bousquet ${ }^{1,2}$, B. Ringeval ${ }^{1}$, I. Pison ${ }^{1}$, E. J. Dlugokencky ${ }^{3}$, E.-G. Brunke ${ }^{4}$, C. Carouge ${ }^{1}$, F. Chevallier ${ }^{1}$, \\ A. Fortems-Cheiney ${ }^{1}$, C. Frankenberg ${ }^{5}$, D. A. Hauglustaine ${ }^{1}$, P. B. Krummel ${ }^{6}$, R. L. Langenfelds ${ }^{5}$, M. Ramonet ${ }^{1}$, \\ M. Schmidt ${ }^{1}$, L. P. Steele ${ }^{5}$, S. Szopa ${ }^{1}$, C. Yver $^{1}$, N. Viovy ${ }^{1}$, and P. Ciais ${ }^{1}$ \\ ${ }^{1}$ Laboratoire des Sciences du Climat et de l'Environnement, IPSL-LSCE, CEA-CNRS-UVSQ, UMR8212 91191, France \\ ${ }^{2}$ Université de Versailles Saint Quentin en Yvelines, France \\ ${ }^{3}$ NOAA Earth System Research Laboratory, Global Monitoring Division, Boulder, CO, USA \\ ${ }^{4}$ South African Weather Service, Stellenbosch, South Africa \\ ${ }^{5}$ Jet Propulsion Laboratory, Pasadena, CA, USA \\ ${ }^{6}$ Centre for Australian Weather and Climate Research/CSIRO, Marine and Atmospheric Research, Victoria, Australia
}

Received: 27 October 2010 - Published in Atmos. Chem. Phys. Discuss.: 12 November 2010

Revised: 29 March 2011 - Accepted: 8 April 2011 - Published: 20 April 2011

\begin{abstract}
The recent increase of atmospheric methane is investigated by using two atmospheric inversions to quantify the distribution of sources and sinks for the 2006-2008 period, and a process-based model of methane emissions by natural wetland ecosystems. Methane emissions derived from the two inversions are consistent at a global scale: emissions are decreased in $2006(-7 \mathrm{Tg})$ and increased in 2007 $(+21 \mathrm{Tg})$ and $2008(+18 \mathrm{Tg})$, as compared to the 1999-2006 period. The agreement on the latitudinal partition of the flux anomalies for the two inversions is fair in 2006, good in 2007 , and not good in 2008. In 2007, a positive anomaly of tropical emissions is found to be the main contributor to the global emission anomalies ( $\sim 60-80 \%)$ for both inversions, with a dominant share attributed to natural wetlands $(\sim 2 / 3)$, and a significant contribution from high latitudes $(\sim 25 \%)$. The wetland ecosystem model produces smaller and more balanced positive emission anomalies between the tropics and the high latitudes for 2006, 2007 and 2008, mainly due to precipitation changes during these years. At a global scale, the agreement between the ecosystem model and the inversions is good in 2008 but not satisfying in 2006 and 2007. Tropical South America and Boreal Eurasia appear to be major contributors to variations in methane emissions consistently in the inversions and the ecosystem model. Finally, changes in $\mathrm{OH}$ radicals during 2006-2008 are found to be less than $1 \%$ in inversions, with only a small impact on the inferred methane emissions.
\end{abstract}

Correspondence to: $\mathrm{P}$. Bousquet (philippe.bousquet@lsce.ipsl.fr)

\section{Introduction}

Atmospheric methane $\left(\mathrm{CH}_{4}\right)$ is a major greenhouse gas and plays a key role in the production of tropospheric ozone (Forster et al., 2007). After a decade of near stable concentrations, the growth rate of atmospheric methane has started to increase again (Rigby et al., 2008), with changes of $8.0 \pm 0.6 \mathrm{ppb}$ in 2007 and $6.3 \pm 0.6 \mathrm{ppb}$ in 2008 (update from Dlugokencky et al., 2009). The main sources of $\mathrm{CH}_{4}$ are natural wetlands, anthropogenic activities (livestock production; rice cultivation; production, storage, transmission, and distribution of fossil fuels; waste waters and landfills), and biomass burning, both natural and human-induced. Global emissions are between 500 and $600 \mathrm{Tg} \mathrm{CH}_{4} \mathrm{yr}^{-1}$, with 60 $70 \%$ being of anthropogenic origin (Denman et al., 2007). The destruction of $\mathrm{CH}_{4}$ by $\mathrm{OH}$ in the troposphere represents about $90 \%$ of the $\mathrm{CH}_{4}$ loss in the atmosphere, making the atmospheric $\mathrm{CH}_{4}$ budget very sensitive to $\mathrm{OH}$ changes. The rest of the sink is due to an uptake of $\mathrm{CH}_{4}$ by soils, reaction with $\mathrm{Cl}$ in the marine boundary layer, and to destruction in the stratosphere by reactions with $\mathrm{OH}, \mathrm{Cl}$, and $\mathrm{O}\left({ }^{1} \mathrm{D}\right)($ Denman et al., 2007).

Because anthropogenic $\mathrm{CH}_{4}$ emissions only change gradually with time, the year-to-year variability of $\mathrm{CH}_{4}$ emissions is controlled by wetland emissions (Bousquet et al., 2006; Chen and Prinn, 2006) and by biomass burning emissions, the latter being estimated to play a significant (Bousquet et al., 2006) or a dominant role (Langenfelds et al., 2002) in particular during climate events such as the 1997-1998 El Niño or the 2002-2003 dry period over the northern midlatitudes (Simmonds et al., 2005). The role of the $\mathrm{OH}$ sink

Published by Copernicus Publications on behalf of the European Geosciences Union. 
in atmospheric $\mathrm{CH}_{4}$ variations may be significant (Bousquet et al., 2005; Prinn et al., 2005; Rigby et al., 2008) but it is still controversial, given discrepancies in the magnitude of $\mathrm{OH}$ interannual variations computed by atmospheric chemistry models $(\sim 1-3 \%$, (Dentener et al., 2003; van Weele et al., 2009) or estimated by atmospheric inversions based on 1,1,1-trichloroethane ( 4-10\%, Bousquet et al., 2005; Krol and Lelieveld, 2003; Prinn et al., 2001).

Several studies have addressed the question of the apparent stabilization of atmospheric methane during 1990s. The collapse of the former USSR economy led to a decrease of $\mathrm{CH}_{4}$ emissions in the 1990s (Dlugokencky et al., 2003). Indeed, the EDGAR4 inventory of anthropogenic emissions (EDGAR4 database: European Commission, 2009) do show a decrease in $\mathrm{CH}_{4}$ emissions from continental Europe (including western Russia) between 1990 and 2005, and a stagnation in North America, but a significant increase from emerging countries, especially China, contributing to an increase in tropical and East Asian $\mathrm{CH}_{4}$ emissions. Overall, global anthropogenic $\mathrm{CH}_{4}$ emissions are estimated to have increased by $32 \mathrm{Tg}$ since 1990 in the EDGAR4 inventory, especially after 1999. In the global inversion of Bousquet et al. (2006), the low growth rates of the late 1990s and early 2000 s, is attributed to competing influences of increasing anthropogenic emissions and decreasing natural wetland emissions, consistent with the EDGAR4 inventory trends and with drier conditions encountered in various regions of the Northern Hemisphere in the late1990s/early 2000s (Hoerling and Kumar, 2003).

Various lines of evidence point to natural wetlands playing a dominant role in the recent increase of $\mathrm{CH}_{4}$ atmospheric growth rate since 2007. Surface temperature and precipitation anomalies during years 2007 and 2008 were large and positive over the main wetland regions emitting $\mathrm{CH}_{4}$. A very high annual mean temperature was recorded over Siberia in 2007 mainly in autumn $\left(+4{ }^{\circ} \mathrm{C}\right.$ compared to $1961-1990$, National Climatic Data Center, 2008), a region with large wetland areas. Tropical areas, strong contributor of wetlands area at a global scale, experienced the 3rd-largest (2007) and the largest (2008) positive precipitation anomalies from 1986 to 2008 (Dlugokencky et al., 2009; Schneider et al., 2008). In the tropics, processes relating to hydrology appear to be the dominant driver of wetland $\mathrm{CH}_{4}$ emissions, whereas temperature is more important at high latitudes (Walter et al., 2001; Ringeval et al., 2010). An analysis of CO observations, a tracer used as a proxy for biomass burning emissions, further indicates that the 2007 positive $\mathrm{CH}_{4}$ growth rate anomaly is not related to biomass burning in northern latitudes (Dlugokencky et al., 2009). Biomass burning in the Tropics could have contributed to the $2007-2008 \mathrm{CH}_{4}$ growth rate anomaly, but not as a dominant factor (Dlugokencky et al., 2009; Rigby et al., 2008). Based on analysis of observations of $\mathrm{CH}_{3} \mathrm{CCl}_{3}$, Dlugokencky et al. (2009) suggest no significant contribution to the $\mathrm{CH}_{4}$ anomaly in 2007 from decreasing $(\mathrm{OH})$, contrary to Rigby et al. (2008) who inferred a $-4 \%$ decrease of $\mathrm{OH}$ from 2006 to 2007 but with a large uncertainty $( \pm 14 \%)$ that make the two estimates statistically compatible.

Atmospheric inversion is a powerful tool to infer the timevarying distribution of regional sources and sinks of $\mathrm{CH}_{4}$ by assimilating atmospheric observations in a model of atmospheric chemistry and transport using prior information of the surface $\mathrm{CH}_{4}$ fluxes (Bousquet et al., 2006; Chen and Prinn, 2006; Bergamaschi et al., 2005; Hein et al., 1997; Houweling et al., 1999). However, as with most top-down approaches using atmospheric observations, atmospheric inversions can hardly provide insights on the underlying processes causing the emissions. On the other hand, ecosystem models computing wetland or fire emissions incorporate knowledge of local processes, but often need additional constraints to up-scale their local estimates to regional and global scales for producing $\mathrm{CH}_{4}$ large-scale emissions that are compatible with the global atmospheric signals (e.g. Spahni et al., 2011).

In this paper, we investigate the changes in atmospheric $\mathrm{CH}_{4}$ for 2006-2008 using the results of two atmospheric inversion models (Bousquet et al., 2006; Pison et al., 2009) and of a recent ecosystem model for $\mathrm{CH}_{4}$ wetland emissions (Ringeval et al., 2011b).

\section{Methods}

\subsection{Inversion models}

We use two different inversion models, both based on the Bayesian formalism. $\mathrm{CH}_{4}$ observations are assimilated into an atmospheric chemical-transport model together with prior information on the spatio-temporal distribution and uncertainties of $\mathrm{CH}_{4}$ sources and sinks, to estimate the magnitude and the uncertainties of optimized surface emissions.

The first inversion model (hereafter referred as INV1) is an analytical inversion that has been used to infer the sources and sinks of $\mathrm{CO}_{2}$ and $\mathrm{CH}_{4}$ (Peylin and Bousquet, 2005; Bousquet et al., 2000, 2005, 2006) and recently $\mathrm{H}_{2}$ (Bousquet et al., 2011). Briefly, it solves for monthly surface $\mathrm{CH}_{4}$ emissions for the different categories of sources and sinks and for 11 large regions (10 land regions +1 ocean), using monthly mean observations at up to 68 surface stations from the NOAA/ESRL, CSIRO and IPSL/LSCE surface monitoring networks. The offline version LMDZt version 3 of the LMDZ-GCM, nudged to analysed winds (Uppala, 2005), is used to model atmospheric transport (Hourdin and Talagrand, 2006; Hourdin et al., 2002). Prior emissions are taken from inventories (Matthews and Fung, 1987; Olivier and Berdowski, 2001; van der Werf et al., 2006). The $\mathrm{OH}$ 3-dimensional fields are pre-optimized by an inversion of $\mathrm{CH}_{3} \mathrm{CCl}_{3}$ (MCF) observations as described in Bousquet et al. (2005). Monthly uncertainties are prescribed for prior $\mathrm{CH}_{4}$ emissions of $\pm 150 \%$ for each region each month, and 
Table 1. Description of the 11 inversions defining INV1 ensemble.

\begin{tabular}{ll}
\hline Scenario & Description \\
\hline $\mathrm{S}_{0}$ & $\begin{array}{l}\text { Reference inversion (see text) } \\
\mathrm{S}_{1}\end{array}$ \\
& $\begin{array}{l}\text { Prior natural wetland emissions based on } \\
\text { Kaplan (2002) instead of Matthews and }\end{array}$ \\
& Fung (1987) \\
$\mathrm{S}_{2}$ & Climatological OH instead of interannually varying \\
$\mathrm{S}_{3}$ & Only NOAA/ESRL observations (up to 50 sites) \\
$\mathrm{S}_{4}$ & Only sites with valid observations along the \\
& 1984-2008 period \\
$\mathrm{S}_{5}$ & All sites with at least 5 yr of measurements \\
$\mathrm{S}_{6}$ & Uncertainties on observations divided by two \\
$\mathrm{S}_{7}$ & Uncertainties on observations multiplied by two \\
$\mathrm{S}_{8}$ & Uncertainties on prior fluxes divided by two \\
$\mathrm{S}_{9}$ & Uncertainties on prior fluxes multiplied by two \\
$\mathrm{S}_{10}$ & No filtering to limit the month-to-month noise in \\
& inferred fluxes (see text) \\
\hline
\end{tabular}

for $\mathrm{CH}_{4}$ observations (from $\pm 5 \mathrm{ppb}$ to $\pm 50 \mathrm{ppb}$, with a median of $\pm 10 \mathrm{ppb}$ ), with no error correlations. A simple filter is also added in the time domain: changes of the inferred fluxes from one month to the next are limited to $\pm 250 \%$ (sources with a seasonal cycle in the prior) or to $\pm 50 \%$ (sources with no seasonal cycle in the prior) of the prior month-to-month differences, according to Peylin et al. (1999, 2002). This noise filter avoids the creation of unrealistic large month-to-month flux differences. A more complete description of the method can be found in Bousquet et al. (2005). We define a reference inversion scenario $\left(\mathrm{S}_{0}\right)$ based on these assumptions, complemented by 10 additional scenarios (Table 1). This ensemble of 11 inversions provides monthlyoptimized $\mathrm{CH}_{4}$ emissions per region and per emitting process, and their residual uncertainties, for the inversion window 1984-2009. In this work the focus is put on the analysis of the 2006-2008 period only.

The second inversion model (here after referred to as INV2) is a variational inversion based on Chevallier et al. (2005) coupled with the Simplified Assimilation Chemical System (SACS) developed by Pison et al. (2009) and the LMDZt transport model version4, which has an improved parametrization of mixing in the planetary boundary layer (Hourdin and Talagrand, 2006) as compared to version3 used in INV1. The SACS assimilation package represents a simplified methane oxidation chain, keeping only the main reactions linking $\mathrm{CH}_{4}$ to $\mathrm{CO}$ and $\mathrm{H}_{2}$, through reactions with hydroxyl radicals $(\mathrm{OH})$ and formaldehyde $(\mathrm{HCHO})$. The reaction between $\mathrm{OH}$ and methyl-chloroform $\left(\mathrm{CH}_{3} \mathrm{CCl}_{3}\right)$ is also represented within the SACS as a constraint on $\mathrm{OH}$ concentrations. Only the total $\mathrm{CH}_{4}$ flux is inferred in INV2, and not the individual source types as in INV1. The prior variance of fluxes in each grid cell are set to $\pm 100 \%$ of the maximum flux over the eight neighbouring grid cells and the current grid cell each month (Pison et al., 2009). The error correlations of the $\mathrm{CH}_{4}$ fluxes are modelled using correlation lengths of $500 \mathrm{~km}$ on land and $1000 \mathrm{~km}$ on oceans, without time correlations (Chevallier et al., 2005). Daily mean $\mathrm{CH}_{4}$ observations at continuous measurement stations and individual flask observations at flask stations are assimilated for the same stations as in INV1 to estimate weekly $\mathrm{CH}_{4}$ emissions at the model resolution. The relevant cost function and the norm of its gradient computed by the adjoint of LMDZt and SACS are minimized with the algorithm M1QN3 (Gilbert and Lemaréchal, 1989). The inversion results consist of eight-day maps (7081 cells) of $\mathrm{CH}_{4}$ emission fluxes and of four correction coefficients for the $\mathrm{OH}$ column abundances of four latitudinal bands of the same surface $\left(90^{\circ} \mathrm{S} / 30^{\circ} \mathrm{S}, 30^{\circ} \mathrm{S}-0^{\circ}, 0^{\circ}-30^{\circ} \mathrm{N}, 30^{\circ} \mathrm{N}-90^{\circ} \mathrm{N}\right)$. INV2 was run from 1990 up to end of 2009 , to avoid border effects, with 43 iterations and more than $99 \%$ reduction of the norm of the gradient of the cost function. A complete description on INV2 can be found in Pison et al. (2009). For comparison, the fluxes from INV2 (global mean of $529 \mathrm{Tg} \mathrm{CH}_{4} \mathrm{yr}^{-1}$ for the period 1999-2006) are scaled to have the same global mean value as in INV1 for the period 1999-2006 (515 $\mathrm{Tg} \mathrm{CH}_{4} \mathrm{yr}^{-1}$ ).

The main advantage of INV1 is the low computing cost because of the large-region approach and of the pre-calculation of transport and chemistry that allows many sensitivity tests to be performed. Also, in INV1, we separate the different source types. The main advantage of INV2 is the estimation of $\mathrm{CH}_{4}$ emissions on a fine grid, the same as the transport model, which avoids aggregation errors in the flux domain (Kaminski et al., 2001), and the assimilation of observations at the time of the measurements (and not as monthly means), which limits the aggregation error in the time domain.

\subsection{Model of natural wetlands emissions}

Wetland $\mathrm{CH}_{4}$ emissions are computed using the global vegetation model ORCHIDEE, which simulates land energy budgets, hydrology and carbon cycling (Krinner et al., 2005), and which has been further developed to compute $\mathrm{CH}_{4}$ emissions from natural wetlands (Ringeval et al., 2010, 2011b). $\mathrm{CH}_{4}$ emissions are computed monthly for each $1^{\circ} \times 1^{\circ}$ model grid cell as the product of an emitting water saturated area by a flux density for the period 1990-2008 (see Appendix). The saturated areas within each grid cell are computed by the subgrid hydrology model TOPMODEL. (Beven and Kirkby, 1979; Ringeval et al., 2011a) and scaled globally to the inundated areas derived from a suite of satellite observations (Prigent et al., 2001, 2007). The wetland $\mathrm{CH}_{4}$ flux density is computed in each grid point using an update of Ringeval et al. (2010) model, which was adapted from the Walter et al. (2001) model. Three pathways of transport (diffusion, plant-mediated transport and ebullition) and oxidation are included. The CRUNCEP dataset developed by Viovy and Ciais (2009) is used to drive the wetland 


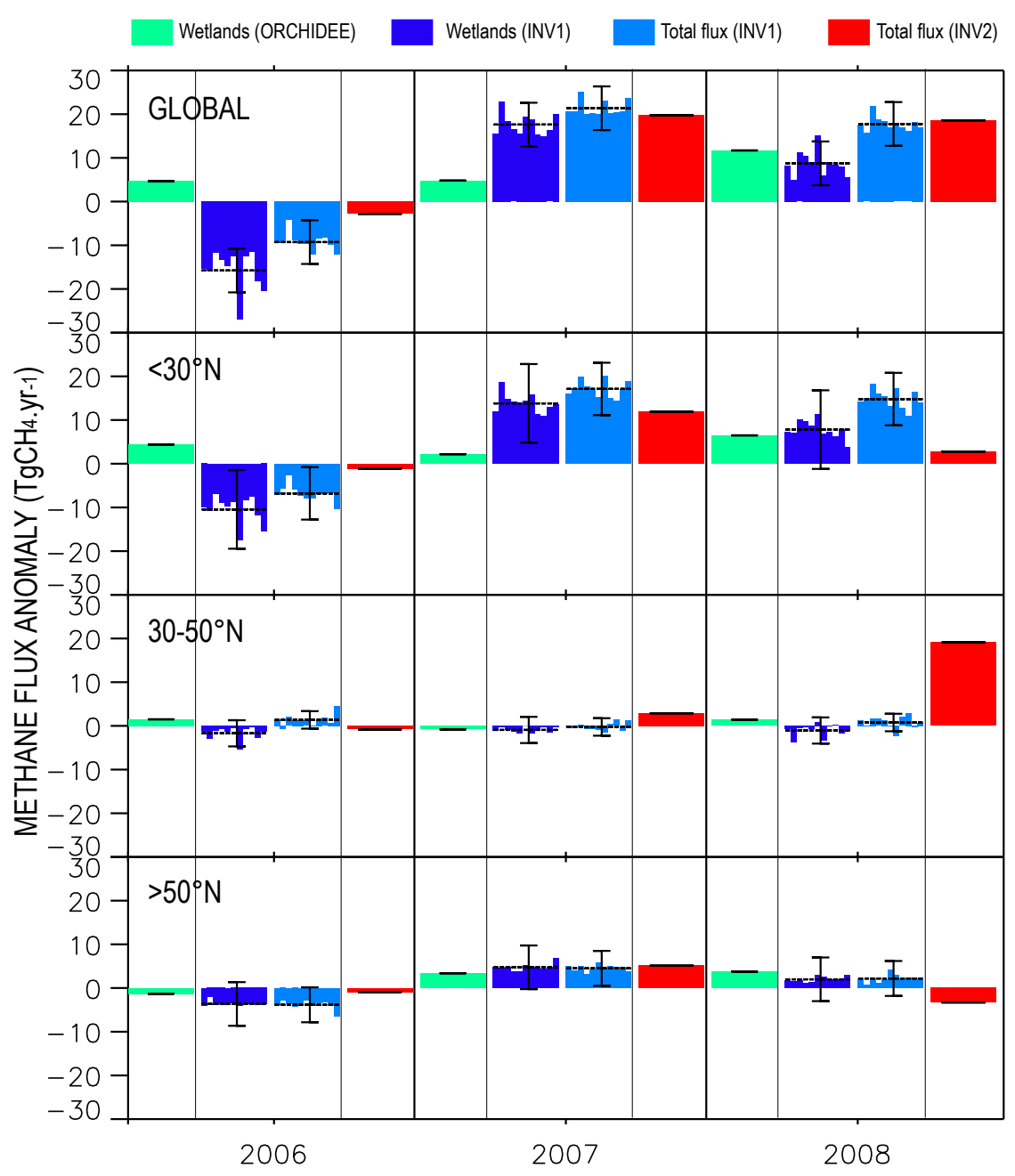

Fig. 1. Anomalies of annual methane emissions in $\mathrm{Tg} \mathrm{CH}_{4} \mathrm{yr}^{-1}$ for 2006 to 2008 . The reference period for the anomaly calculation is 19992006. From left to right, each year: wetland anomalies from ORCHIDEE model (green), wetland anomalies from INV1 (11 inversions, dark blue), total anomalies from INV2 (11 inversions, light blue), and total anomalies from INV2 (red). The dark line for each model represents the mean of the performed simulations. From top to bottom: global, $<30^{\circ} \mathrm{N}, 30-50^{\circ} \mathrm{N},>50^{\circ} \mathrm{N}$. Error bars represent the residual uncertainty returned by the inversion INV1 (1-sigma).

emission model over the 1990-2008 period (Appendix A). For comparison, the fluxes from ORCHIDEE (global mean of $206 \mathrm{Tg} \mathrm{CH}_{4} \mathrm{yr}^{-1}$ for the period 1999-2006) are scaled to have the same global mean value as in INV1 for the period 1999-2006 (165 $\left.\mathrm{Tg} \mathrm{CH}_{4} \mathrm{yr}^{-1}\right)$.

\section{Results}

We use the 8-yr period 1999-2006 during which atmospheric $\mathrm{CH}_{4}$ abundance was rather stable (Table 2), as a reference period to calculate annual emission anomalies in 2006, 2007 and 2008 (Fig. 1, Table 3) for natural wetland $\mathrm{CH}_{4}$ emissions (ORCHIDEE and INV1) and for total $\mathrm{CH}_{4}$ emissions (INV1 and INV2). As INV2 does not separate source types, only the total $\mathrm{CH}_{4}$ flux can be compared with INV1 total $\mathrm{CH}_{4}$ flux.

\subsection{Global scale}

At a global scale, the two inversions provide a consistent picture of $\mathrm{CH}_{4}$ total emission anomalies (Fig. 1, Table 3), with a negative anomaly in $2006(-10 \pm 4 \mathrm{Tg}$ for INV1 and $-3 \mathrm{Tg}$ for INV2), followed by a positive anomaly in 2007 ( $21 \pm 4 \mathrm{Tg}$ and $20 \mathrm{Tg})$ and in $2008(17 \pm 4 \mathrm{Tg}$ and $19 \mathrm{Tg})$. This makes average $\mathrm{CH}_{4}$ emission anomalies of $-7 \mathrm{Tg}$ in $2006,+21 \mathrm{Tg}$ in 2007 , and $+18 \mathrm{Tg}$ in 2008 , as seen by the two inversions. These anomalies are statistically significant considering the residual uncertainties for INV1. In INV1, the global emission variations are dominated by natural wetlands in 2006 and 2007, and by a mix of all sources in 2008. In INV1, the positive emission anomalies from natural wetlands represents $\sim 80 \%$ of the 2007 global flux anomaly and $\sim 50 \%$ in 2008. This result is robust across the 11 inversions of the 
Table 2. Methane surface fluxes averaged for the 1999-2006 period, in $\mathrm{Tg} \mathrm{CH}_{4} \mathrm{yr}^{-1}$. From left to right, $\mathrm{CH}_{4}$ fluxes are given: for natural wetlands from ORCHIDEE model, for four categories of emissions inferred by INV1 (wetlands, other natural, biomass burning, total), and for the total emissions inferred by INV2. For INV1, values are the mean of the 11 inversion performed. From top to bottom: global, $<30^{\circ} \mathrm{N}$, $30-50^{\circ} \mathrm{N},>50^{\circ} \mathrm{N}$. Total fluxes are the sum of surface emissions and soil uptake. The uncertainty assigned to INV1 is the residual uncertainty returned by the inversion procedure (1-sigma). For INV1, regional fluxes are not shown for sources other than wetlands, as we do not discuss their anomalies (Table 3), which are generally very small.

\begin{tabular}{|c|c|c|c|c|c|c|c|}
\hline \multirow{2}{*}{$\begin{array}{l}\mathrm{TgCH}_{4} \mathrm{yr}^{-1} \\
\text { Region }\end{array}$} & \multicolumn{7}{|c|}{ 1999-2006 period } \\
\hline & Orchidee & $\begin{array}{r}\text { INV1 } \\
\text { Natural } \\
\text { Wetlands }\end{array}$ & $\begin{array}{l}\text { INV1 } \\
\text { Other } \\
\text { natural }\end{array}$ & $\begin{array}{c}\text { INV1 } \\
\text { Biomass } \\
\text { burning }\end{array}$ & $\begin{array}{c}\text { INV1 } \\
\text { Anthropic }\end{array}$ & $\begin{array}{r}\text { INV1 } \\
\text { Total }\end{array}$ & $\begin{array}{r}\text { INV2 } \\
\text { Total }\end{array}$ \\
\hline Global & $165^{*}$ & $165 \pm 9$ & $17 \pm 9$ & $36 \pm 5$ & $297 \pm 15$ & $515 \pm 3$ & $515 * *$ \\
\hline$<30^{\circ} \mathrm{N}$ & 109 & $115 \pm 9$ & - & - & - & $304 \pm 6$ & 290 \\
\hline $30-50^{\circ} \mathrm{N}$ & 34 & $19 \pm 4$ & - & - & - & $136 \pm 6$ & 143 \\
\hline$>50^{\circ} \mathrm{N}$ & 22 & $31 \pm 5$ & - & - & - & $76 \pm 4$ & 86 \\
\hline
\end{tabular}

* ORCHIDEE global emissions for the 1999-2006 period (206 $\mathrm{Tg} \mathrm{CH}_{4} \mathrm{yr}^{-1}$ ) were scaled to the wetland emissions estimate from scenario $\mathrm{S}_{0}$ of INV1 for the same period $\left(165 \mathrm{Tg} \mathrm{CH}_{4} \mathrm{yr}^{-1}\right)$. ** INV2 global total flux for the $1999-2006$ period $\left(529 \mathrm{Tg} \mathrm{CH}_{4} \mathrm{yr}^{-1}\right)$ was scaled to the global total flux from the scenario $\mathrm{S}_{0}$ of INV1 for the same period $\left(515 \mathrm{Tg} \mathrm{CH}_{4} \mathrm{yr}^{-1}\right)$.

Table 3. Methane surface flux anomalies for 2006 (a), 2007 (b), and for 2008 (c), relative to the 1999-2006 period (see Table 2), in $\mathrm{Tg} \mathrm{CH}_{4} \mathrm{yr}^{-1}$. From left to right, $\mathrm{CH}_{4}$ fluxes are given: for natural wetlands from ORCHIDEE model, for four categories of emissions inferred by INV1 (wetlands, other natural, biomass burning, total), and for the total emissions inferred by INV2. From top to bottom: global, $<30^{\circ} \mathrm{N}, 30-50^{\circ} \mathrm{N},>50^{\circ} \mathrm{N}$. Total fluxes are the sum of surface emissions and soil uptake. The first uncertainty assigned to INV1 is the residual uncertainty returned by the inversion procedure (1-sigma). The second uncertainty is the spread of the 11 inversions of INV1 (1-sigma). For INV1, regional anomalies are not shown for sources other than wetlands as generally very small.

\begin{tabular}{|c|c|c|c|c|c|c|c|}
\hline \multirow{2}{*}{$\begin{array}{l}\mathrm{Tg} \mathrm{CH}_{4} \mathrm{yr}^{-1} \\
\text { REGION }\end{array}$} & \multicolumn{7}{|c|}{ a: 2006 anomaly } \\
\hline & ORCHIDEE & $\begin{array}{r}\text { INV1 } \\
\text { Natural } \\
\text { wetlands }\end{array}$ & $\begin{array}{l}\text { INV1 } \\
\text { Other } \\
\text { natural }\end{array}$ & $\begin{array}{c}\text { INV1 } \\
\text { Biomass } \\
\text { burning }\end{array}$ & $\begin{array}{c}\text { INV1 } \\
\text { Anthropic }\end{array}$ & $\begin{array}{r}\text { INV1 } \\
\text { Total }\end{array}$ & $\begin{array}{r}\text { INV2 } \\
\text { Total }\end{array}$ \\
\hline Global & 5 & $-16 \pm 9 \pm 3$ & $0 \pm 1 \pm 1$ & $-1 \pm 5 \pm 2$ & $7 \pm 6 \pm 2$ & $-10 \pm 4 \pm 4$ & -3 \\
\hline$<30^{\circ} \mathrm{N}$ & 4 & $-11 \pm 9 \pm 3$ & - & - & - & $-7 \pm 6 \pm 4$ & -1 \\
\hline $30-50^{\circ} \mathrm{N}$ & 2 & $-1 \pm 4 \pm<1$ & - & - & - & $1 \pm 6 \pm 2$ & -1 \\
\hline$>50^{\circ} \mathrm{N}$ & -1 & $-4 \pm 5 \pm<1$ & - & - & - & $-4 \pm 4 \pm 4$ & -1 \\
\hline $\mathrm{TgCH}_{4} \mathrm{yr}^{-1}$ & \multicolumn{7}{|c|}{ b: 2007 anomaly } \\
\hline REGION & ORCHIDEE & $\begin{array}{r}\text { INV1 } \\
\text { Natural } \\
\text { wetlands }\end{array}$ & $\begin{array}{c}\text { INV1 } \\
\text { Other } \\
\text { natural }\end{array}$ & $\begin{array}{c}\text { INV1 } \\
\text { Biomass } \\
\text { burning }\end{array}$ & $\begin{array}{c}\text { INV1 } \\
\text { Anthropic }\end{array}$ & $\begin{array}{r}\text { INV1 } \\
\text { Total }\end{array}$ & $\begin{array}{r}\text { INV2 } \\
\text { Total }\end{array}$ \\
\hline Global & 5 & $17 \pm 9 \pm 3$ & $0 \pm 1 \pm 1$ & $3 \pm 5 \pm 1$ & $2 \pm 6 \pm 2$ & $21 \pm 4 \pm 4$ & 20 \\
\hline$<30^{\circ} \mathrm{N}$ & 2 & $14 \pm 9 \pm 3$ & - & - & - & $17 \pm 6 \pm 4$ & 12 \\
\hline $30-50^{\circ} \mathrm{N}$ & -1 & $-1 \pm 4 \pm<1$ & - & - & - & $0 \pm 6 \pm 2$ & 3 \\
\hline$>50^{\circ} \mathrm{N}$ & 4 & $5 \pm 5 \pm<1$ & - & - & - & $5 \pm 4 \pm 4$ & 5 \\
\hline $\mathrm{TgCH}_{4} \mathrm{yr}^{-1}$ & \multicolumn{7}{|c|}{ c: 2008 anomaly } \\
\hline REGION & ORCHIDEE & $\begin{array}{r}\text { INV1 } \\
\text { Natural } \\
\text { wetlands }\end{array}$ & $\begin{array}{c}\text { INV1 } \\
\text { Other } \\
\text { natural }\end{array}$ & $\begin{array}{c}\text { INV1 } \\
\text { Biomass } \\
\text { burning }\end{array}$ & $\begin{array}{c}\text { INV1 } \\
\text { Anthropic }\end{array}$ & $\begin{array}{l}\text { INV1 } \\
\text { Total }\end{array}$ & $\begin{array}{r}\text { INV2 } \\
\text { Total }\end{array}$ \\
\hline Global & 11 & $8 \pm 6 \pm 5$ & $0 \pm 1 \pm 1$ & $3 \pm 5 \pm 2$ & $6 \pm 6 \pm 4$ & $17 \pm 4 \pm 4$ & 19 \\
\hline$<30^{\circ} \mathrm{N}$ & 6 & $8 \pm 9 \pm 4$ & - & - & - & $14 \pm 7 \pm 4$ & 3 \\
\hline $30-50^{\circ} \mathrm{N}$ & 1 & $-1 \pm 3 \pm 1$ & - & - & - & $1 \pm 7 \pm 2$ & 20 \\
\hline$>50^{\circ} \mathrm{N}$ & 4 & $2 \pm 5 \pm 1$ & - & - & - & $2 \pm 5 \pm 1$ & -3 \\
\hline
\end{tabular}


INV1 ensemble. The inversion using another wetland distribution (scenario $S_{1}$, Table 1) produces the largest departure from the reference scenario $S_{0}$ in 2007 (largest flux anomaly due to wetlands) and 2008 (smallest flux anomaly due to wetlands). This result illustrates the importance of the choice of the prior estimates and distributions of wetland emissions. In 2006, the scenario with tight errors on $\mathrm{CH}_{4}$ observations $\left(\mathrm{S}_{6}\right.$, Table 1) produces the largest negative anomaly in wetland emissions, as a better fit to observations requires larger changes in the surface fluxes. Another critical point for the robustness of inverted fluxes appears to be the extension of the inversion period one year after the last year of analysis. Indeed, if the inversion stops at the end of 2008, the results for INV1 are significantly modified, showing the importance of 2009 observations to constrain 2008 surface fluxes.

The optimized $\mathrm{OH}$ fields are lower by $1 \%$ and $0.5 \%$ in INV1 and INV2 respectively in 2007 and 2008, as compared to 2006. Therefore more $\mathrm{CH}_{4}$ emissions are required to match the global growth rate constraint when not accounting for $\mathrm{OH}$ changes. Indeed, if $\mathrm{OH}$ radicals are maintained constant from one year to the next (sensitivity inversion $\mathrm{S}_{2}$ of INV1, see Table 1), the positive anomalies of 2007 and 2008 are larger by $4 \mathrm{Tg}$ as compared to $\mathrm{S}_{0}$. This small $\mathrm{OH}$ variability is qualitatively, but not quantitatively, in agreement with the results of Rigby et al. (2008), as they find a much larger decrease in $\mathrm{OH}$ in $2007(-4 \pm 14 \%)$, implying a smaller increase in methane emissions in 2007 than in our study. Neither the simultaneous MCF inversion performed in INV2, nor the offline MCF inversion performed in INV1, supports large variations of $\mathrm{OH}$ from one year to the next as in Rigby et al. (2008), Our results are also consistent with the recent work of Montzka et al. (2011) who inferred only a small interannual $\mathrm{OH}$ variability over the last decade.

The ORCHIDEE model provides a global positive flux anomaly for the three years 2006-2008 (as compared to the reference period 1999-2006). There is a good agreement of ORCHIDEE with the wetland flux anomaly inferred by INV1 in 2008. However, in 2007, the positive wetland flux anomaly given by the ecoystsem model $(+5 \mathrm{Tg})$ is only one third of the wetland anomaly inferred by INV1 $(+17 \mathrm{Tg})$. In 2006, ORCHIDEE does not agree on the sign of the anomaly with both inversions (see latitudinal analyses in the next sections).

In INV1, other sources than natural wetlands contributing to the 2007 flux anomaly are biomass burning $(+3 \pm 5 \mathrm{Tg}$, mostly in South America) and anthropogenic sources $(+2 \pm 6 \mathrm{Tg})$. Contributions from landfills, mostly in Asia, dominate the anthropogenic inverted flux anomaly in 2007 (not shown). In 2008, the anthropogenic flux anomaly $(+6 \pm 6 \mathrm{Tg})$ explains $35 \%$ of the positive flux anomaly in INV1 with contributions from rice in Asia, ruminant animals, and landfills. The biomass burning anomaly explains the remaining $18 \%(+3 \pm 5 \mathrm{Tg})$. The partition between these sources may be uncertain because of the negative correlations of error existing between them (e.g. between biomass burn- ing and anthropogenic emissions). Error correlations can be computed using the posterior covariance matrix calculated during the inverse procedure in INV1. If one assumes that errors are proportional to fluxes, as error correlations between two source types/regions get closer to -1 , these two source types/regions are less and less well separated by the atmospheric observations. We find rather small error correlations between individual source types at a global scale, as they range from 0 to -0.55 . This result, although only qualitative, indicates a rather good capacity of INV1 to separate the different methane source types at a global scale.

The partition between anthropogenic and natural anomalies in methane emissions reveals that, although dominated by changes in natural wetland emissions, anthropogenic emissions contribute significantly to the global emission anomaly at a rate ranging from 2 to $5 \mathrm{Tg} \mathrm{CH}_{4} \mathrm{yr}^{-1}$ for the 2006-2008 period. Indeed, the new EDGAR4.1 database (EDGAR4.1 database: European Commission, 2009) shows that the trend of anthropogenic $\mathrm{CH}_{4}$ emissions has been, on average, of $+6 \mathrm{Tg} \mathrm{CH}_{4} \mathrm{yr}^{-1}$ for the 1999-2005 period. Bousquet et al. (2006) proposed that this increase has been hidden by a simultaneous decrease in wetland emissions due to droughts in the northern hemisphere. After 2006, the results proposed here by INV1 is an increase of wetland emissions together with an increase of anthropogenic emissions at a slower rate than estimated by EDGAR4.1 for the 1999-2005 period, but still faster than the mean growth rate of anthropogenic emissions for the 1970-2005 period.

\subsection{Tropics}

Tropical emissions are the largest contributor to the global anomalies of $\mathrm{CH}_{4}$ emissions over 2006-2008 for both inversions, with the exception of INV2 in 2008. In 2007, higher $\mathrm{CH}_{4}$ emissions from tropical regions explain $80 \%$ (INV1) and $60 \%$ (INV2) of the global flux anomaly. Natural wetlands dominate the tropical flux anomalies in INV1, which attributes $82 \%$ of the Tropical flux anomaly and $67 \%$ of the global flux anomaly in 2007 to natural tropical wetlands (Table 3). In 2008, both inversions find a smaller tropical anomaly than in 2007 but the reduction is much more pronounced for INV2 $(+3 \mathrm{Tg}$ ) than for INV1 (still $+14 \pm 7 \mathrm{Tg}$ ). About $60 \%$ of this tropical anomaly is attributed to natural wetlands by INV1, the rest being spread over other types of sources.

As already noticed for the global scale, the magnitude of the $\mathrm{CH}_{4}$ emission anomalies from tropical wetlands found by INV1 is not in agreement with the ecosystem model ORCHIDEE in 2006 and 2007, but agrees well in 2008. Moreover, the positive anomalies found in ORCHIDEE for tropical regions increase from 2006 to 2008, which is not the case in INV1 (Fig. 1). We have investigated further this issue by looking at the three tropical large regions: tropical South America, tropical Africa, and tropical South Asia. It 
appears that South America contributes 90\% of the 2006 and $2007 \mathrm{CH}_{4}$ emission anomalies from tropical wetlands, and $50 \%$ of the 2008 one. Sensitivity tests realized after removing or increasing the year-to-year variability of the precipitation forcing used in ORCHIDEE, show that tropical wetland emissions are mostly driven by precipitations (not shown), through the wetland extent (Ringeval et al., 2011a). If one removes the year-to-year variability in precipitations, a smaller and negative anomaly is found in 2006 , more consistent with INV1 results. In the tropics, 2006, 2007 and 2008 are years of positive anomalies in precipitations, especially over the wetland regions (Dlugokencky et al., 2009). Also, observed tropical land precipitation anomalies are weaker in 2007 than in $2008(+3 \%$ vs. $+10 \%)$, which can explain the increase of the ORCHIDEE computed $\mathrm{CH}_{4}$ flux anomalies between 2007 and 2008. Thus, the dominant control of $\mathrm{CH}_{4}$ tropical wetland emissions by precipitations can explain both the positive anomaly in 2006-2008 and the positive trend from 2006 to 2008 in the ORCHIDEE model. ORCHIDEE may overstate the control of wetland emissions (product of a wetland extent by a flux density) by precipitations. First, tropical floodplains are not explicitly represented in the model and thus cannot buffer the effect of precipitations on wetland extent. Second, modelled wetland extent increases continuously with precipitations but "in reality", this expansion does not necessary lead to a raise in methane emissions, for instance if inundation happens over a non-rich carbon soil. Third, larger precipitations may lead to an increase of $\mathrm{CH}_{4}$ oxidation in the water above the ground, thus limiting methane flux density to the atmosphere. This last effect is not included in Walter et al. (2001) model and thus in ORCHIDEE yet.

In INV1, the largest flux anomalies are found in South America, and in Africa. However, few surface observations are available to constrain the inversion over these two regions, making the inversion estimate more uncertain than for any other region. In this context, the space-based instrument SCIAMACHY on ENVISAT can provide independent information on the variability of $\mathrm{CH}_{4}$ atmospheric columnaveraged mixing ratios particularly over tropical regions (Frankenberg et al., 2008). The SCIAMACHY retrievals from Frankenberg et al. (2008) show a negative anomaly over South America and Africa of about 5-6 ppb in 2006 (as compared to 2003-2009 average), which is qualitatively consistent with the negative emission anomaly inferred by INV1 for these tropical regions. We further compared the SCIAMACHY $\mathrm{CH}_{4}$ column anomaly over South America with the $\mathrm{CH}_{4}$ column anomaly computed by LMDZt using optimized fluxes from INV1 and INV2 (Fig. 2) for the period 20062008. Both inversions show a minimum in tropical $\mathrm{CH}_{4}$ column-averaged mixing ratio in mid-2006, which is consistent with the SCIAMACHY data, albeit less pronounced and shifted by 2-3 months. In 2007 and 2008, the two inversions and SCIAMACHY retrievals agree very well on the relative magnitude of the methane increase in the atmosphere

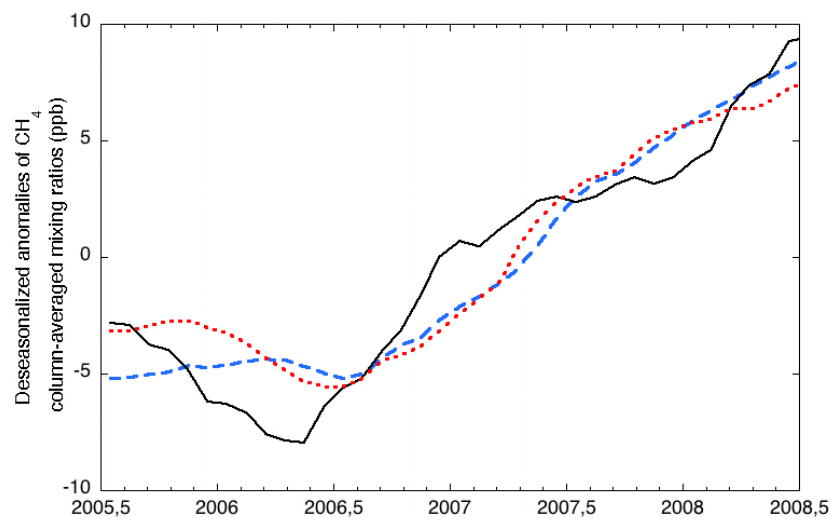

Fig. 2. Mean $\mathrm{CH}_{4}$ column-averaged mixing ratio anomalies for South America for the 2005-2008 period (in ppb), as retrieved by SCIAMACHY on ENVISAT (solid black), by INV1 (dashed blue) and by INV2 (dotted red). A 12-month running mean was applied to the monthly column-averaged mixing ratios, and their mean over 2006-2008 was subtracted to compute the anomaly.

for South America (Fig. 2) and also for other tropical regions (not shown). This shows a consistency between tropical $\mathrm{CH}_{4}$ flux changes inferred from surface-based inversions and from independent satellite data of column-averaged mixing ratios. However, this agreement also reveals that we cannot really discriminate the significant tropical negative anomalies inferred by INV1 $(-7 \pm 6 \mathrm{Tg})$ from the small negative anomaly of INV2 (only $-1 \mathrm{Tg}$ ) over South America in 2006 using the SCIAMACHY data. Indeed, this indicates that SCIAMACHY retrievals may not be very sensitive to the amplitude of regional anomalies of the surface fluxes, but probably integrates larger regions.

\subsection{Mid latitudes}

At mid latitudes $\left(30-50^{\circ} \mathrm{N}\right)$, the $\mathrm{CH}_{4}$ anomalies are not statistically different from zero for the different models. This is interesting because the mid-latitudes contain $30 \%$ of the global source, but this source seems to vary little from one year to the next. One exception is inversion INV2 in 2008 (anomaly of $+20 \mathrm{Tg}$ ). This large anomaly is hard to explain because there is less wetland area present at mid latitudes (only 14\% of the global wetland source) and anthropogenic emissions are unlikely to vary that much from one year to the next. INV2 may produce more variability at mid latitudes because of the assimilation of daily data from 5 continuous stations at these latitudes. These continuous data increase the relative weight of mid latitudes in the cost function from less than $25 \%$ in INV1 to more than $33 \%$ in INV2, as compared to other latitudes. When tightening the prior uncertainties on these five sites in INV2 from $\pm 15 \mathrm{ppb}$ (reference case) down to $\pm 3 \mathrm{ppb}$, the variability at mid-latitudes increases even more (not shown). As we assimilate an increasing number of types of observation in atmospheric 
inversions (flasks, continuous, aircraft, and satellites), the relative weights among these data appears to be an issue that will have to be further investigated as initiated in Bergamaschi et al. (2009).

\subsection{High latitudes}

At high latitudes $\left(>50^{\circ} \mathrm{N}\right)$, the two inversions provide total flux anomalies of the same sign in 2006 and 2007 but not in 2008, although only the 2007 anomalies are significant considering the residual uncertainties for INV1 (Table 3). In 2007, a consistent positive wetland emission anomaly of $+5 \pm 5 \mathrm{Tg}$ (INV1) and $+4 \mathrm{Tg}$ (ORCHIDEE) is found, explaining the total boreal positive anomaly of INV1 $(+5 \pm 4 \mathrm{Tg})$ and possibly explaining the one of INV2 $(+5 \mathrm{Tg})$. In the inversions, the boreal total flux anomaly represents about $25 \%$ of the 2007 global flux anomaly. In ORCHIDEE, boreal wetland anomalies explain $\sim 50 \%$ (2007) and 35\% (2008) of the global wetland anomalies, which represents a larger contribution than inferred by INV1 ( 25\% in 2007 and 30\% in 2008), especially in 2007. Again, ORCHIDEE provides more balanced anomalies between boreal and tropical regions.

In ORCHIDEE, the 2007 and 2008 positive anomalies are of the same magnitude (Table 3), and Boreal Eurasia explains $\sim 100 \%$ (2007) and 68\% (2008) of the boreal anomalies. We find that the 2007 positive anomaly is due to higher temperatures and changes in precipitations impacting both methane flux densities and wetland extent, especially during summer and autumn. In INV1, boreal America and boreal Eurasia are found to have contributed almost equally to the positive flux anomaly. This may reflect a difficulty for the inversion to partition emissions between these two regions with regional error correlations reaching $-0.3 /-0.4$ in INV1.

In 2007, the boreal $\mathrm{CH}_{4}$ flux anomaly represents only $30 \%$ (INV1) and 40\% (INV2) of the tropical flux anomaly. This result may appear to contradict the larger anomaly in atmospheric surface growth rate found by Dlugokencky et al. (2009) at high latitudes as compared to the tropics. To investigate this issue, we have performed a test with the LMDZt model. A pulse of $1 \mathrm{Tg}$ of $\mathrm{CH}_{4}$ was emitted over one month for each of the two regions: Boreal Eurasia $\left(13\right.$ millions $\left.\mathrm{km}^{2}\right)$ and tropical Asia $\left(6\right.$ millions $\left.\mathrm{km}^{2}\right)$. After the month of emission, the flux pulses were transported for 11 months, with no chemistry applied. The resulting mean atmospheric surface $\mathrm{CH}_{4}$ mixing ratios induced by each pulse are very different (Fig. 3a, b), because atmospheric transport is horizontally efficient at high latitudes but vertically efficient in the tropics to disperse $\mathrm{CH}_{4}$. (Fig. 3c, black and red lines). Note that, for this analysis, the computed surface $\mathrm{CH}_{4}$ mixing ratios were rescaled on a grid with cells of equal surface. As a consequence, the maximum impact of a $1 \mathrm{Tg}$ pulse at neighbouring surface stations is found to be 2 to 3 times larger at high latitudes as compared to the tropics (Fig. 3c). Inversions account for these regional differences in
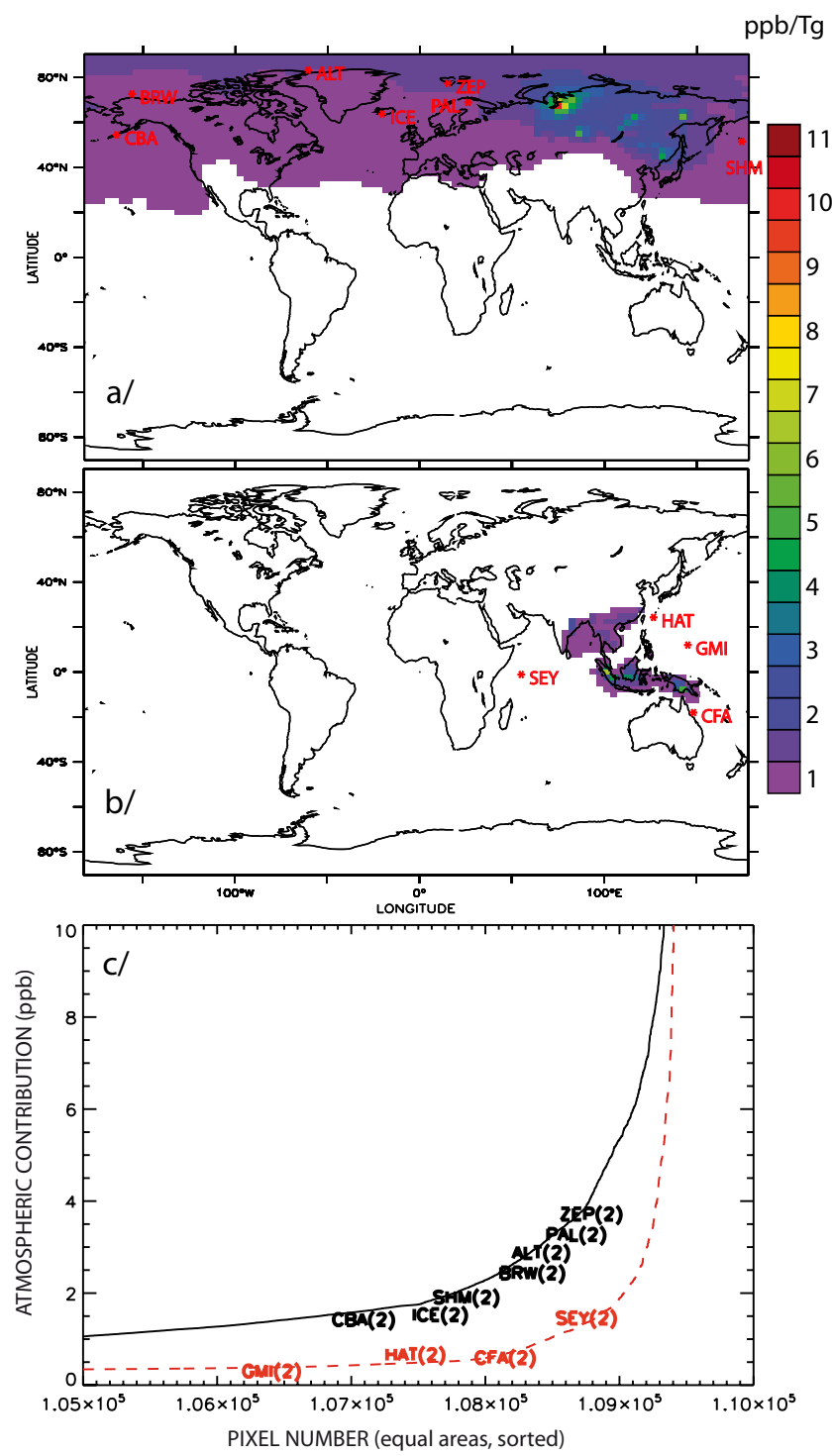

Fig. 3. Impact at the surface of a $1 \mathrm{Tg} \mathrm{CH}_{4}$ pulse emitted from two regions (see text): boreal Asia and tropical Asia. (a) Mean plume for Boreal Asia, computed as the mean of the 12 monthly plumes generated by 1 month of emission followed by 11 months of transport without emission (in $\mathrm{ppb} \mathrm{Tg}^{-1} \mathrm{CH}_{4}$ ); (b) same as (a) for tropical Asia. (c) Maximum increase in mixing ratio detected for all transport model pixels, at the surface, for emissions in boreal Asia (black solid line) or in tropical Asia (red dashed line). Model pixels have the same surface in order to normalize the comparison between a boreal and a tropical region. Model pixels are sorted by increasing values for each emitting region. Only pixels with the largest mixing ratios are kept for the plot. Maximum values at model pixels containing atmospheric measurement stations used in the inversion are plotted above the lines, as the name of the stations. The month when the maximum is reached is plotted as a number in parentheses. Locations of the stations are shown in (a) and (b). 
vertical mixing, and place accordingly the inferred wetland anomaly more in the tropics than at high latitudes. Finally, the inferred bottom-up and top-down flux anomalies inferred in 2007 are consistent with the larger atmospheric surface growth rate observed at high latitudes. This shows that flux anomalies cannot be just deduced from inspection of surface atmospheric data, but that atmospheric transport must be explicitly and properly modelled.

\section{Conclusions}

We have analyzed recent changes in the $\mathrm{CH}_{4}$ budget using two atmospheric inversions (INV1 and INV2) and the wetland ecosystem emission model ORCHIDEE over the period 2006-2008:

- A consistent picture has been obtained for the two inversions at a global scale with a negative flux anomaly in 2006 ( -10 and $-3 \mathrm{Tg}$ ), followed by positive flux anomalies in 2007 (21 and 20 Tg) and 2008 (17 and $19 \mathrm{Tg})$.

- The inversion inferring the different sources and sinks of methane separately (INV1) reveals that tropical natural wetlands are a dominant contributor to the global flux anomalies (from $50 \%$ to $100 \%$ ) over the period 2006-2008.

- This dominant tropical contribution for the flux anomalies is shown to be consistent with the observation of a more pronounced increase in near surface methane atmospheric growth rate at high latitudes, because the dilution of surface fluxes by convection is strong in the tropics and weak at high latitudes.

- In 2006, both inversions find a negative tropical anomaly but the ORCHIDEE model does not agree on a strong contribution from tropical wetlands as in INV1, and computes a positive anomaly due to abnormal tropical precipitations mainly over South America

- In 2007, a dominant tropical contribution to the positive global flux anomaly is found by the two inversions (60-80\%), with a significant role of high latitudes $(\sim 25 \%)$. Tropical natural wetlands are found to explain $\sim 2 / 3$ of the global anomaly, boreal wetlands explaining about $30 \%$. The ORCHIDEE model agrees on the sign of the anomaly but neither on its magnitude $(5 \mathrm{Tg}$ ) nor on its latitudinal partition with a comparable contribution from high latitudes ( $3 \mathrm{Tg}$ ) and from tropical regions $(2 \mathrm{Tg})$. The response of the ORCHIDEE model to precipitations mainly controls the methane flux in the tropics and both precipitations and temperature play a role at high latitudes.

- In 2008, a dominant tropical contribution to the positive global flux anomaly is found by INV1, which is consistent with the ORCHIDEE model. Tropical wetlands are found to explain about 50\% of the global anomaly (INV1), the rest being spread among anthropogenic emissions and biomass burning. On the contrary, INV2 locates most of the 2008 flux anomaly at mid latitudes.

- The atmospheric $\mathrm{CH}_{4}$ variations computed with the optimized emissions of the two inversions for 20062008 are shown to be consistent with independent $\mathrm{CH}_{4}$ column-averaged mixing ratio retrieved by SCIAMACHY satellite instrument.

- Finally, $\mathrm{OH}$ changes remain small $(<1 \%)$ in both inversions and only slightly modulate methane fluxes.

Although there is not yet a complete agreement between the different approaches presented in this work, their similarities and differences allow to gain knowledge about the driving forces of the methane cycle, and to get work directions for future improvements in the estimation of global to regional methane emission variations.

Here, we have illustrated that natural wetlands can largely modulate the atmospheric growth rate of methane over a few years. Nevertheless, as long as global methane anthropogenic emissions increase, as estimated by bottom-up inventories such as EDGAR4.1 ( $>+40 \mathrm{Tg}$ globally since the early 1980s), one should not forget that, even without counting possible future releases from marine hydrates or permafrost, methane should continue to increase in the atmosphere on decadal time scales. In 2009, atmospheric methane increased by $\sim 5 \mathrm{ppb}$, slightly lower than the increases of $8.0 \mathrm{ppb}$ in 2007 and $6.3 \mathrm{ppb}$ in 2008 based on updated NOAA global averages ( $1 \sigma$ uncertainties are $\pm 0.6 \mathrm{ppb}$ ). It is too soon to tell if the 2007 to 2009 period was a temporary positive anomaly such as $1997-1998$ or 2002-2003, but, at this stage, this recent anomaly is the largest and most persistent one since systematic observations began.

\section{Appendix A}

\section{ORCHIDEE ecosystem model for methane wetland emissions}

$\mathrm{CH}_{4}$ emissions are computed monthly (mass per month) for each model grid cell as the product of a wetland extent (surface per month) and of a process-based $\mathrm{CH}_{4}$ flux densitiy (mass per month and per surface) for the period 1990-2008.

Wetland area dynamics are computed by the inclusion of TOPMODEL (Beven and Kirkby, 1979) with bias correction of Saulnier and Datin (2004) into ORCHIDEE. For each grid cell, using both topographic heterogeneities and soil moisture computed by ORCHIDEE, a sub-grid saturated fraction (i.e. water table at the soil surface) is computed, as well as fractions with water table at various depths. The simulated 
space-time distribution of saturated soils is evaluated globally (Ringeval et al., 2011a) against inundated area derived from a suite of satellite observations from multiple sensors of Prigent et al. (2001, 2007). As explained in Ringeval et al. (2011b), we use Prigent et al. (2001) satellite data to represent wetland areas and compute anomalies from the saturated area given by TOPMODEL, relatively to the 19932000 climatology given by the satellite data. Moreover, in the present work, for boreal ecosystems, resulting wetlands are further filtered using soil organic carbon data as done by Wania et al. (2010) to diagnose the presence of peatlands. In boreal regions, wetlands are assimilated to peatlands with a large soil carbon content. Soil carbon accumulation under anaerobic conditions is necessary to provide substrate for methanogenic microbes. Thus not only saturated conditions but also enough soil carbon content is required to have $\mathrm{CH}_{4}$ emissions at high latitudes. Because ORCHIDEE is not able to produce peat accumulation yet (see Koven et al., 2009), resulting wetlands fractions are further multiplied, for boreal ecosystems, by a map giving fractional peatland cover per grid-cell. This map is obtained by using soil organic carbon data from IGBP DIS at high resolution $\left(5^{\prime} \times 5^{\prime}\right)$, by dividing each pixel of this database by $130 \mathrm{~kg} \mathrm{~m}^{-3}$ (which is the maximum soil carbon density of peat), and then by regridding the result at $1^{\circ} \times 1^{\circ}$ resolution (Lawrence and Slater, 2007). The hypothesis underlying the multiplication of the two products (map of peatland cover and map of inundated areas) is that the inundated fraction is the same for an entire grid-cell as for a sub-grid peatland into this grid-cell.

$\mathrm{CH}_{4}$ fluxes are computed using an update of the processbased model of Walter et al. (2001) for each sub-grid watertable class given by TOPMODEL. The model simulates $\mathrm{CH}_{4}$ production, three pathways of transport (diffusion, plantmediated transport and ebullition) and oxidation. Contrary to initial version of Walter et al. (2001), the substrate for methanogenesis is computed from active soil organic carbon computed by ORCHIDEE (see Ringeval et al. (2010) for more details). Identification of each grid-cell to a wetland type is based on preponderant vegetation type.

After a spin-up using pre-industrial conditions and transient simulations over 1860-1990 (Ringeval et al., 2011b), ORCHIDEE is run over the 1990-2008 period to analyze recent year-to-year variability. Over this last period, ORCHIDEE is forced by the CRUNCEP dataset developed by Viovy and Ciais (2009). Briefly, this dataset is based, on the one hand, on the monthly data from the Climatic Research Unit of University of East Anglia (CRU) and, on the other hand, on NCEP data to generate the diurnal and the daily variabilities.

Global mean wetland $\mathrm{CH}_{4}$ emissions simulated by ORCHIDEE are $\sim 206 \mathrm{Tg} \mathrm{CH}_{4} \mathrm{yr}^{-1}$ over the 1999-2006 period. This is at the upper end of the IPCC range (Denman et al., 2007). The distribution over latitude bands is 28,43 , and $135 \mathrm{Tg} \mathrm{CH}_{4} \mathrm{yr}^{-1}$ for boreal $\left(>50^{\circ} \mathrm{N}\right)$, temperate $\left(30^{\circ} \mathrm{N}-\right.$ $\left.50^{\circ} \mathrm{N}\right)$ and tropical wetlands $\left(30^{\circ} \mathrm{S}-30^{\circ} \mathrm{N}\right)$, respectively.
For comparison, the global emissions of ORCHIDEE $\left(\sim 206 \mathrm{Tg} \mathrm{CH}_{4} \mathrm{yr}^{-1}\right.$ ) are scaled each year according to the global emission from natural wetlands estimated by INV1 for the reference period 1999-2006 $\left(\sim 165 \mathrm{Tg} \mathrm{CH}_{4} \mathrm{yr}^{-1}\right)$. A scaling ratio of 0.8 is therefore applied for the years 2006 to 2008 to ORCHIDEE wetland emissions.

Acknowledgements. French Atomic agency (CEA) and Laboratoire des Sciences du Climat et de l'Environnement (LSCE) are to be thanked for providing computing time to this work. Part of this work is funded by French CNRS and by EU projects HYMN (Peter van Velthoven) and NITROEUROPE (inversion component: Peter Bergamaschi). We acknowledge G. Van der Werf for providing $\mathrm{CH}_{4}$ emissions from fires and J. Kaplan for providing the $\mathrm{CH}_{4}$ emission maps from wetlands, to the NITROEUROPE project. We acknowledge the TRANSCOM community for the region map used in this work. Nathalie de Noblet (LSCE) and Pierre Friedlingstein (University of Bristol/LSCE) must be thanked for fruitful discussion on ORCHIDEE model. C. Prigent (Paris observatory) and F. Papa (GISS/USA) can be thanked to have provided the inundation maps used in ORCHIDEE model for 1993-2000.

Edited by: B. N. Duncan

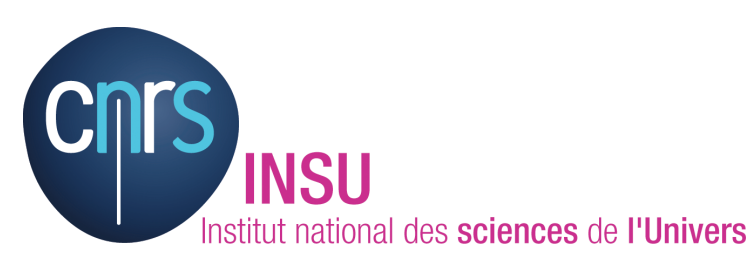

The publication of this article is financed by CNRS-INSU.

\section{References}

Bergamaschi, P., Krol, M., Dentener, F., Vermeulen, A., Meinhardt, F., Graul, R., Ramonet, M., Peters, W., and Dlugokencky, E. J.: Inverse modelling of national and European $\mathrm{CH}_{4}$ emissions using the atmospheric zoom model TM5, Atmos. Chem. Phys., 5, 2431-2460, doi:10.5194/acp-5-2431-2005, 2005.

Bergamaschi, P., Frankenberg, C., Meirink, J. F., Krol, M., Villani, M. G., Houweling, S., Dentener, F., Dlugokencky, E. J., Miller, J. B., Gatti, L. V., Engel, A., and Levin, I.: Inverse modeling of global and regional $\mathrm{CH}_{4}$ emissions using SCIAMACHY satellite retrievals, J. Geophys. Res.-Atmos., 114, D22301, doi:10.1029/2009JD012287, 2009.

Beven, K. and Kirkby, M.: A physically based, variable contributing area model of basin hydrology, Hydrolog. Sci. J., 24, 43-69, 1979.

Bousquet, P., Peylin, P., Ciais, P., Le Quere, C., Friedlingstein, P., and Tans, P. P.: Regional changes in carbon dioxide fluxes of land and oceans since 1980, Science, 290, 1342-1346, 2000.

Bousquet, P., Hauglustaine, D. A., Peylin, P., Carouge, C., and Ciais, P.: Two decades of $\mathrm{OH}$ variability as inferred by an inversion of atmospheric transport and chemistry of methyl chloroform, Atmos. Chem. Phys., 5, 2635-2656, doi:10.5194/acp-52635-2005, 2005. 
Bousquet, P., Ciais, P., Miller, J. B., Dlugokencky, E. J., Hauglustaine, D. A., Prigent, C., Van der Werf, G. R., Peylin, P., Brunke, E. G., Carouge, C., Langenfelds, R. L., Lathiere, J., Papa, F., Ramonet, M., Schmidt, M., Steele, L. P., Tyler, S. C., and White, J.: Contribution of anthropogenic and natural sources to atmospheric methane variability, Nature, 443, 439-443, 2006.

Bousquet, P., Yver, C., Pison, I., Li, Y. S., Fortems, A., Hauglustaine, D., Szopa, S., Rayner, P., Novelli, P. C., Langenfelds, R., Steele, L. P., Ramonet, M., Schmidt, M., Foster, P., Morfopoulos, C., and Ciais, P.: A 3D synthesis inversion of the molecular hydrogen cycle: sources and sinks budget and implications for the soil uptake, J. Geophys. Res., 116, D01302, doi:10.1029/2010JD014599, 2011.

Chen, Y. H. and Prinn, R. G.: Estimation of atmospheric methane emissions between 1996 and 2001 using a three-dimensional global chemical transport model, J. Geophys. Res.-Atmos., 111, D10307, doi:10.1029/2005JD006058, 2006.

Chevallier, F., Fisher, M., Peylin, P., Serrar, S., Bousquet, P., Bréon, F.-M., Chédin, A., and Ciais, P.: Inferring $\mathrm{CO}_{2}$ sources and sinks from satellite observations: Method and application to TOVS data, J. Geophys. Res., 110, D24309, doi:24310.21029/22005JD006390, 2005.

Denman, K. L., Brasseur, G., Chidthaisong, A., Ciais, P., Cox, P. M., Dickinson, R. E., Hauglustaine, D., Heinze, C., Holland, E., Jacob, D., Lohmann, U., Ramachandran, S., da Silva Dias, P. L., Wofsy, S. C., and Zhang, X.: Couplings Between Changes in the Climate System and Biogeochemistry, in: Climate Change 2007: The Physical Science Basis. Contribution of Working Group I to the Fourth Assessment Report of the Intergovernmental Panel on Climate Change, edited by: Solomon, S., Qin, D., Manning, M., Chen, Z., Marquis, M., Averyt, K. B., Tignor, M., and Miller, H. L., Cambridge University Press, Cambridge, UK and New York, NY, USA, 2007.

Dentener, F., Peters, W., Krol, M., van Weele, M., Bergamaschi, P., and Lelieveld, J.: Interannual variability and trend of $\mathrm{CH}_{4}$ lifetime as a measure for $\mathrm{OH}$ changes in the 1979-1993 time period, J. Geophys. Res.-Atmos., 108, 4442, doi:4410.1029/2002JD002916, 2003.

Dlugokencky, E. J., Bruhwiler, L., White, J. W. C., Emmons, L. K., Novelli, P. C., Montzka, S. A., Masarie, K. A., Lang, P. M., Crotwell, A. M., Miller, J. B., and Gatti, L. V.: Observational constraints on recent increases in the atmospheric $\mathrm{CH}$ burden, Geophys. Res. Lett., 36, L18803, doi:10.1029/2009GL039780, 2009.

Emission Database for Global Atmospheric Research (EDGAR), release version 4.1. European Commission, Joint Research Centre (JRC)/Netherlands Environmental Assessment Agency (PBL), http://edgar.jrc.ec.europa.eu, last access: 18 April 2011, 2010.

Forster, P., Ramaswamy, V., Artaxo, P., Berntsen, T., Betts, R., Fahey, D. W., Haywood, J., Lean, J., Lowe, D. C., Myhre, G., Nganga, J., Prinn, R., and Raga, G., M. S. a. R. V. D.: Changes in Atmospheric Constituents and in Radiative Forcing, in: Climate Change 2007: The Physical Science Basis. Contribution of Working Group I to the Fourth Assessment Report of the Intergovernmental Panel on Climate Change, edited by: Solomon, S., Qin, D., Manning, M., Chen, Z., Marquis, M., Averyt, K. B., Tignor, M., and Miller, H. L., Cambridge University Press, Cambridge, UK and New York, NY, USA, 2007.
Frankenberg, C., Bergamaschi, P., Butz, A., Houweling, S., Meirink, J. F., Notholt, J., Petersen, A. K., Schrijver, H., Warneke, T., and Aben, I.: Tropical methane emissions: A revised view from SCIAMACHY onboard ENVISAT, Geophys. Res. Lett., 35, L15811, doi:10.1029/2008GL034300, 2008.

Gilbert, J.-C. and Lemaréchal, C.: Some numerical experiments with variable-storage quasi-Newton algorithms, Math. Program., 45, 407-435, 1989.

Hein, R., Crutzen, P. J., and Heimann, M.: An inverse modeling approach to investigate the global atmospheric methane cycle, Global. Biogeochem. Cy., 11, 43-76, 1997.

Hoerling, M. and Kumar, A.: The perfect ocean for drought, Science, 299, 691-694, 2003.

Hourdin, F. and Talagrand, O.: Eulerian backtracking of atmospheric tracers. I: Adjoint derivation and parametrization of subgrid-scale transport, Q. J. Roy. Meteor. Soc., 132, 567-583, 2006.

Hourdin, F. D., Couvreux, F., and Menut, L.: Parameterization of the dry convective boundary layer based on a mass flux representation of thermals, J. Atmos. Sci., 59, 1105-1123, 2002.

Houweling, S., Kaminski, T., Dentener, F., Lelieveld, J., and Heimann, M.: Inverse modeling of methane sources and sinks using the adjoint of a global transport model, J. Geophys. Res.Atmos., 104, 26137-26160, 1999.

Kaminski, T., Rayner, P. J., Heimann, M., and Enting, I. G.: On aggregation errors in atmospheric transport inversions, J. Geophys. Res.-Atmos., 106, 4703-4715, 2001.

Kaplan, J. O.: Wetlands at the Last Glacial Maximum: Distribution and methane emissions, Geophys. Res. Lett., 29, 1079, doi:10.1029/2001g1013366, 2002.

Krinner, G., Viovy, N., de Noblet-Ducoudre, N., Ogee, J., Polcher, J., Friedlingstein, P., Ciais, P., Sitch, S., and Prentice, I. C.: A dynamic global vegetation model for studies of the coupled atmosphere-biosphere system, Global. Biogeochem. Cy., 19, GB1015, doi:1010.1029/2003GB002199, 2005.

Krol, M. and Lelieveld, J.: Can the variability in tropospheric $\mathrm{OH}$ be deduced from measurements of 1,1,1-trichloroethane (methyl chloroform)?, J. Geophys. Res.-Atmos., 108, 4125, doi:4110.1029/2002JD002423, 2003.

Langenfelds, R. L., Francey, R. J., Pak, B. C., Steele, L. P., Lloyd, J., Trudinger, C. M., and Allison, C. E.: Interannual growth rate variations of atmospheric $\mathrm{CO}_{2}$ and its delta $\mathrm{C}-13, \mathrm{H}-2, \mathrm{CH}_{4}$, and CO between 1992 and 1999 linked to biomass burning, Global. Biogeochem. Cy., 16, 1048, doi:1010.1029/2001GB001466, 2002.

Lawrence, D. M. and Slater, A. G.: Incorporating orgainc soil into a global climate model, Clim. Dynam., 30(2-3), 145-160, doi:10.1007/s00382-007-0278-1, 2007

Matthews, E. and Fung, I.: Methane emissions from natural wetlands, global distribution, area and environmental characteristics of sources, Global. Biogeochem. Cy., 1, 61-86, 1987.

Montzka, S. A., Krol, M., Dlugokencky, E., Hall, B., Jockel, P., and Lelieveld, J.: Small Interannual Variability of Global Atmospheric Hydroxyl, Science, 331, 67-69, doi:10.1126/science.1197640, 2011.

National Climatic Data Center databasis, available at: http://www. ncdc.noaa.gov/climate-monitoring/, last access: 11 April 2011, 2008.

Olivier, J. G. J. and Berdowski, J. J. M.: Global emissions sources 
and sinks, in: The Climate System, edited by: Berdowski, J., Guichert, R., and Heij, B., 33-37, 2001.

Peylin, P. and Bousquet, P.: Multiple constraints on regional $\mathrm{CO}_{2}$ flux variations over land and oceans, Global. Biogeochem. Cy., 19, GB1011, doi:1010.1029/2003GB002214, 2005.

Peylin, P., Bousquet, P., Ciais, P., and Monfray, P.: Time-Dependant vs Time-Independant inversion of the atmospheric $\mathrm{CO}_{2}$ observations: consequences for the regional fluxes, in: Inverse methods in global biogeochemical cycles, Geophysical Monograph 114, edited by: Kashibata, P., Heimann, M., Rayner, P., Mahowald, N., Prinn, R. G., and Hartley, D. E., American Geophysical Union,, Washington, DC, 1999.

Peylin, P., Baker, D., Sarmiento, J., Ciais, P., and Bousquet, P.: Influence of transport uncertainty on annual mean and seasonal inversions of atmospheric $\mathrm{CO}_{2}$ data, J. Geophys. Res.-Atmos., 107, 4385, doi:10.1029/2001JD000857, 2002.

Pison, I., Bousquet, P., Chevallier, F., Szopa, S., and Hauglustaine, D.: Multi-species inversion of $\mathrm{CH}_{4}, \mathrm{CO}$ and $\mathrm{H}_{2}$ emissions from surface measurements, Atmos. Chem. Phys., 9, 5281-5297, doi:10.5194/acp-9-5281-2009, 2009.

Prigent, C., Matthews, E., Aires, F., and Rossow, W. B.: Remote sensing of global wetland dynamics with multiple satellite data sets, Geophys. Res. Lett., 28, 46310-4634, doi:4610.1029/2001GL013263, 2001.

Prigent, C., Papa, F., Aires, F., Rossow, W. B., and Matthews, E.: Global inundation dynamics inferred from multiple satellite observations, 1993-2000, J. Geophys. Res.-Atmos., 112, D12107, doi:10.1029/2006jd007847, 2007.

Prinn, R. G., Huang, J., Weiss, R. F., Cunnold, D. M., Fraser, P. J., Simmonds, P. G., McCulloch, A., Harth, C., Salameh, P., O'Doherty, S., Wang, R. H. J., Porter, L., and Miller, B. R.: Evidence for substantial variations of atmospheric hydroxyl radicals in the past two decades, Science, 293, 1048-1048, 2001.

Prinn, R. G., Huang, J., Weiss, R. F., Cunnold, D. M., Fraser, P. J., Simmonds, P. G., McCulloch, A., Harth, C., Reimann, S., Salameh, P., O’Doherty, S., Wang, R. H. J., Porter, L. W., Miller, B. R., and Krummel, P. B.: Evidence for variability of atmospheric hydroxyl radicals over the past quarter century, Geophys. Res. Lett., 32, L07809, doi:07810.01029/02004GL022228, 2005.

Rigby, M., Prinn, R. G., Fraser, P. J., Simmonds, P. G., Langenfelds, R. L., Huang, J., Cunnold, D. M., Steele, L. P., Krummel, P. B., Weiss, R. F., O'Doherty, S., Salameh, P. K., Wang, H. J., Harth, C. M., Muhle, J., and Porter, L. W.: Renewed growth of atmospheric methane, Geophys. Res. Lett., 35, L22805, doi:10.1029/2008g1036037, 2008.

Ringeval, B., de Noblet-Ducoudre, N., Ciais, P., Bousquet, P., Prigent, C., Papa, F., and Rossow, W. B.: An attempt to quantify the impact of changes in wetland extenton methane emissions at the seasonal and interannual time scales, Global Biogeochem. Cy., 24, GB2003, doi:10.1029/2008GB003354, 2010.

Ringeval, B., Decharme, B., Piao, S. L., Ciais, P., Papa, F., DeNoblet Ducoudré, N., Prigent, C., Friedlingstein, P., Gouttevin, I., and Koven, C.: Modelling sub-grid soil moisture saturation in the ORCHIDEE global land surface model: evaluation against river discharges and remotely sensed data, under review for $\mathbf{J}$. Geophys. Res.-biogeo., 2011a.
Ringeval, B., Friedlingstein, P., Koven, C., Ciais, P., de NobletDucoudré, N., Decharme, B., and Cadule, P.: Climate$\mathrm{CH}_{4}$ feedback from wetlands and its interaction with the climate- $\mathrm{CO}_{2}$ feedback, Biogeosciences Discuss., 8, 3203-3251, doi:10.5194/bgd-8-3203-2011, 2011 b.

Saulnier G.-M. and Datin R., Analytical solution to a bias in the TOPMODEL framework balance, Hydrol. Process, 18, 11951218, 2004.

Schneider, U., Fuchs, T., Meyer-Christoffer, A., and Rudolf, B.: Global precipitation analysis products of the GPCC, Global Precipitation Climatology Centre (GPCC), DWD, Internet Publikation, 1-12, 2008.

Simmonds, P. G., Manning, A. J., Derwent, R. G., Ciais, P., Ramonet, M., Kazan, V., and Ryall, D.: A burning question. Can recent growth rate anomalies in the greenhouse gases be attributed to large-scale biomass burning events?, Atmos. Environ., 39, 2513-2517, 2005.

Spahni, R., Wania, R., Neef, L., van Weele, M., Pison, I., Bousquet, P., Frankenberg, C., Foster, P. N., Joos, F., Prentice, I. C., and van Velthoven, P.: Constraining global methane emissions and uptake by ecosystems, Biogeosciences Discuss., 8, 221-272, doi:10.5194/bgd-8-221-2011, 2011.

Uppala, S. M., Koallberg, P. W., Simmons, A. J., Andrae, U., da Costa Bechtold, V., Fiorino, M., Gibson, J. K., Haseler, J., Hernandez, A., Kelly, G., Li, X., Onogi, K., Saarinen, S., Sokka, N., Allan, R. P., Andersson, E., Arpe, K., Balmaseda, M. A., Beljaars, A. C. M., van de Berg, L., Bidlot, J., Bormann, N., Caires, S., Chevallier, F., Dethof, A., Dragosavac, M., Fisher, M., Fuentes, M., Hagemann, S., Holm, E., Hoskins, B. J., Isaksen, L., Janssen, P. A. E. M., Jenne, R., McNally, A. P. A., Mahfouf, J.-F., Morcrette, J.-J., Rayner, N. A., Saunders, R. W., Simon, P., Sterl, A., Trenberth, K. E., Untch, A., Vasiljevic, D., Viterbo, P., and Woollen, J.: The ERA-40 Reanalysis, J. Roy. Met. Soc., 131, 2961-3012, 2005.

van der Werf, G. R., Randerson, J. T., Giglio, L., Collatz, G. J., Kasibhatla, P. S., and Arellano Jr., A. F.: Interannual variability in global biomass burning emissions from 1997 to 2004, Atmos. Chem. Phys., 6, 3423-3441, doi:10.5194/acp-6-3423-2006, 2006.

van Weele, M., Neef, L., and van Velthoven, P.: Observationbased constraints on the present-day atmospheric methane budget, Geochimica et Cosmochimica Acta, 19th Annual VM Goldschmidt Conference Davos, SWITZERLAND, 21 June, 73, A1374-A1374, 2009.

Viovy, N. and P. Ciais, A combined dataset for ecosystem modelling, available at: http://dods.extra.cea.fr/data/p529viov/ cruncep/readme.htm, last access: 11 March 2011, 2009.

Walter, B. P., Heimann, M., and Matthews, E.: Modeling modern methane emissions from natural wetlands 2 . Interannual variations 1982-1993, J. Geophys. Res.-Atmos., 106, 34207-34219, 2001.

Wania, R., Ross, I., and Prentice, I. C.: Implementation and evaluation of a new methane model within a dynamic global vegetation model: LPJ-WHyMe v1.3.1, Geosci. Model Dev., 3, 565-584, doi:10.5194/gmd-3-565-2010, 2010. 